\title{
Ovine White-Liver Disease (OWLD). Trace Elements in Liver
}

\author{
By Martha J. Ulvund
}

State Veterinary Research Station for Small Ruminants, Sandnes, Norway.

\begin{abstract}
Ulvund, M. J.: Ovine white-liver disease (OWLD). Trace elements in liver. Acta vet. scand. 1990, 31, 297-307. - Trace elements in liver were examined in vitamin $B_{12}$ deficient lambs which developed ovine white-liver disease (OWLD), in cobalt/ vitamin $B_{12}$ supplemented lambs on the same pastures as well as clinically healthy, but sometimes subclinical $B_{12}$ deficient lambs on other pastures $(\mathrm{H})$. Liver Co was marginal to deficient in both OWLD lambs (S lambs) and $\mathrm{H}$ lambs. Supplementation with $\mathrm{B}_{12}$ or Co elevated liver Co. Liver copper was significantly lower in OWLD lambs than in the $\mathrm{H}$ lambs, and $\mathrm{Co} / \mathrm{B}_{12}$ supplementation on pasture generally had no significant effect on the contents. Dosing lambs on OWLD pastures with copper oxide needles (SCuO), however, resulted in high/toxic liver $\mathrm{Cu}$. Dosing with $\mathrm{Co}, \mathrm{Se}$ and $\mathrm{Cu}$ glass boluses resulted in adequate liver $\mathrm{Cu}$, except for 1 lamb with toxic amounts indicating dissolution and absorption of the bolus. OWLD lambs had significantly lower liver molybdenum than $H$ lambs, and $\mathrm{Co} / \mathrm{B}_{12}$ supplementation elevated values, while $\mathrm{CuO}$ treatment depressed them. Liver zinc, manganese and selenium are also reported.
\end{abstract}

sheep; cobalt/vitamin $B_{12}$ deficiency; trace element interferences; copper.

\section{Introduction}

An interaction between cobalt and copper has been detected in ovine white-liver disease (OWLD). Although the $\mathrm{Cu}$ content in OWLD pasture grass was poor (Ulvund \& Pestalozzi 1990b), Cu supplementation or $\mathrm{Cu}$ treatment of already affected lambs worsened the OWLD condition (Ulvund 1990c, d). Serum $\mathrm{Cu}$ was generally higher in OWLD lambs than in cobalt/vitamin $B_{12}$ supplemented lambs grazing the same pastures, and $B_{12}$ treatment of affected lambs lowered $\mathrm{Cu}$ values (Ulvund 1990c, d). Subclinically $B_{12}$ deficient lambs on other pastures $(\mathrm{H})$ also had higher serum $\mathrm{Cu}$ than $\mathrm{Co} / \mathrm{B}_{12}$ supplemented controls on these pastures.

There are few earlier reports on trace elements in the liver of OWLD lambs. Deficient liver Co values were found by Ric- hards \& Harrison (1981) and Mitchell et al. (1982). The same authors found normal liver $\mathrm{Cu}$, while Mason \& McKay (1983) reported low liver $\mathrm{Cu}$ in OWLD lambs.

The fact that $B_{12}$ deficient lambs on some pastures develop OWLD while on other pastures they do not, together with the indication that $\mathrm{Cu}$ or other elements may be involved in the OWLD pathogenesis, necessitated the examination of trace elements in the livers of these lambs.

\section{Materials and methods}

Liver samples were collected from vitamin $B_{12}$ deficient lambs which developed ovine white-liver disease (OWLD, S lambs), from lambs supplemented with cobalt, $\mathrm{B}_{12}$, selenium or copper on the same pastures (SCo, $\mathrm{SCo}, \mathbf{S B}_{12}$, SCopell, SCoSeCu, SSe lambs), and from clinically healthy, but sometimes 
subclinically $\mathrm{B}_{12}$ deficient lambs on other pastures (H lambs). Survey and experimental design has been given earlier (Ulvund \& Pestalozzi 1990a, Ulvund 1990a,d). Group symbols are explained in Tables 3-5.

Altogether 89 livers from 3 years of experiments $(1982,1984,1985)$ were examined. During all years, liver samples were taken at slaughter at the end of the grazing period in September/October. One year (1982), single lambs from various groups were killed at regular intervals throughout the grazing season, and the livers were examined. The liver samples were frozen $\left(\div 20^{\circ} \mathrm{C}\right)$ within 2 $\mathrm{h}$ after slaughter/killing and forwarded to the performing laboratory.

The samples were examined by the following governmental laboratories: The Chemical Research Laboratory (CRL, Agricultural College of Norway, Ås-NLH), The National Veterinary Institute (NVI, Veterinærinstituttet, Oslo), and the National Veterinary Institute (SVA, Statens Veterinærmedicinska Anstalt, Uppsala, Sweden), as shown in Table 1.

Flameless atomic absorption spectrophotometry (AAS, grafite oven) was used by CRL to determine $\mathrm{Co}$ and $\mathrm{Cu}, \mathrm{Mn}$ was deter- mined by flame AAS, Mo by spectrophotometry, and total sulphur by spectrophotometric determination of turbidity $\left(\mathrm{BaSO}_{4}\right.$ suspension, Halvorsen 1989). NVI-Oslo used flame AAS for the determination of $\mathrm{Cu}$ and $\mathrm{Zn}$, flameless AAS for the determination of Mo, and a fluorimetric or a hydride generator method for the determination of Se (Norheim 1989). At SVA-Uppsala, preparation and examination of the samples were performed according to Frank (1976) and Frank \& Petersson (1983) using simultaneous multi-element analysis in a d.c. plasma-atomic emission spectrometer apparatus. The accuracy of the analytical values was checked by referring to certified values of elements in the National Bureau of Standards (NBS) Standard Reference Material, bovine liver SRM 1577. Blind parallels were included and the divergence in results as within acceptable limits.

Liver content of trace elements is sometimes given on dry weight basis (dw), sometimes on wet weight basis (ww). In comparing results given on different scales, an average of $30 \%$ dry matter in the liver was used as recommended by others (Froslie 1977).

Table 1. Chemical examination of liver samples from lambs stratified by year and date of slaughter, variables examined, and performing laboratory.

\begin{tabular}{|c|c|c|c|c|}
\hline Year & $\begin{array}{l}\text { Date of } \\
\text { slaughter }\end{array}$ & $\begin{array}{l}\text { Number } \\
\text { of lambs }\end{array}$ & Variables & $\begin{array}{l}\text { Performing } \\
\text { laboratory }\end{array}$ \\
\hline 1982 & Var.* & 16 & $\begin{array}{l}\text { Co, } \mathrm{Cu}, \mathrm{Mo}, \mathrm{Mn} \text {, } \\
\text { total sulphur }\end{array}$ & CRL, Ås-NLH \\
\hline 1982 & Oct. 11 & 22 & $\begin{array}{l}\text { Co, } \mathrm{Cu}, \mathrm{Mo}, \mathrm{Mn} \text {, } \\
\text { total sulphur }\end{array}$ & CRL, Ås-NLH \\
\hline 1984 & Sept. 26 & 24 & Co & SVA-Uppsala \\
\hline 1984 & Sept. 26 & 24 & $\mathrm{Cu}, \mathrm{Mo}, \mathrm{Zn}, \mathrm{Se}$ & NVI-Oslo \\
\hline 1985 & Oct. 8 & 27 & $\mathrm{Co}, \mathrm{Cu}, \mathrm{Fe}, \mathrm{Mn}, \mathrm{Zn}$ & SVA-Uppsala \\
\hline 1985 & Oct. 8 & 27 & $\mathrm{Se}$ & NVI-Oslo \\
\hline
\end{tabular}

* Different dates of slaughter throughout the experimental period 1982. 
Table 2. Liver $\mathrm{Co}, \mathrm{Cu}, \mathrm{Mo}$, and $\mathrm{Mn}(\mathrm{mg} / \mathrm{kg}$ wet weight) in individual lambs slaughtered in 1982. The lambs were grazing OWLD pastures (S) or pastures where lambs have been growing well $(\mathrm{H})$.

\begin{tabular}{lllllllll}
\hline & & \multicolumn{7}{c}{ Time slaughtered } \\
\cline { 2 - 9 } & Group & May 24 & June 4 & June 11 & July 7 & July 13 & Aug. 11 & Oct. 7 \\
\hline $\mathrm{Co}$ & $\mathrm{S}$ & 0.014 & 0.028 & $<0.010$ & 0.010 & $<0.010$ & 0.011 & 0.021 \\
& $\mathrm{SB}_{12}$ & 0.038 & 0.057 & 0.039 & - & 0.059 & 0.045 & - \\
& $\mathrm{H}$ & $<0.010$ & 0.013 & 0.021 & - & - & 0.022 & - \\
\hline $\mathrm{Cu}$ & $\mathrm{S}$ & 23 & 15 & 12 & 4.6 & 8.9 & 5.6 & 3.6 \\
& $\mathrm{SB} 12$ & 47 & 7.5 & 10 & - & 2.8 & 2.7 & - \\
& $\mathrm{H}$ & 36 & 19 & 16 & - & - & 5.2 & - \\
\hline $\mathrm{Mo}$ & $\mathrm{S}$ & 0.89 & 0.86 & 0.27 & 0.44 & 0.22 & 0.17 & 0.40 \\
& $\mathrm{SB} 12$ & 0.58 & 1.01 & 0.82 & - & 0.93 & 0.71 & - \\
& $\mathrm{H}$ & 0.94 & 0.33 & 0.79 & - & - & 1.09 & - \\
\hline $\mathrm{Mn}$ & $\mathrm{S}$ & 3.5 & 2.9 & 3.1 & 3.3 & 4.8 & 2.5 & 4.1 \\
& $\mathrm{SB} 12$ & 2.9 & 2.9 & 3.1 & - & 2.1 & 1.7 & - \\
& $\mathrm{H}$ & 4.9 & 4.8 & 3.1 & - & - & 2.4 & - \\
\hline
\end{tabular}

$\mathrm{SB}_{12}$ : Lambs grazing OWLD pastures, injected fortnightly with hydroxocobalamin $(2 \mathrm{mg})$.

Localization of pellets in the forestomacs of dosed lambs was verified at slaughter.

\section{Results}

At the end of grazing, mean liver Co was below $0.025 \mathrm{mg} / \mathrm{kg} \mathrm{ww}$ in both the unsupplemented $\mathrm{S}$ lambs (OWLD lambs) and the $\mathrm{H}$ lambs (Tables 3-5), and values were similarly low already from May (Table 2). Regular $\mathrm{B}_{12}$ injections of $\mathrm{S}$ lambs $\left(\mathrm{SB}_{12}\right)$ elevated liver Co throughout grazing (Table 2), and at slaughter these lambs had significantly higher liver Co than the $S$ lambs $(p<0.05$, Tables 3-5). Co supplementation (SCo, $\mathrm{SCo}$, SCopell) also elevated liver Co (Tables 3-5), as did dosing with CoSeCure pellets (Table 5), and Se dosing ( $p<0.025$, Table 5). The livers of the $\mathrm{CuO}$ dosed lambs were further depleted of $\mathrm{Co}(\mathrm{p}<0.05$, Table 4).

Liver $\mathrm{Cu}$ is shown in Tables 2-5. Liver $\mathrm{Cu}$ was generally lower in $\mathrm{S}$ lambs than in $\mathrm{H}$ lambs. Values decreased evenly in all lambs already from pasture outlet in May (Table 2). At the end of grazing, the difference between the $\mathrm{H}$ and $\mathrm{S}$ lambs was significant ( $\mathrm{p}$ $<0.05)$ in 1982 and 1985. Regular $B_{12}$ injections or Co supplementation of $S$ lambs had no significant effect on liver $\mathrm{Cu}$.

Dosing 1 month old $\mathrm{S}$ lambs with $\mathrm{CuO}$ at pasture outlet resulted in toxic amounts of $\mathrm{Cu}$ in the liver at slaughter 4 months later (Table 4). CuO treatment of 2 lambs, 4-5 months old, affected with OWLD (Ulvund 1990d) resulted in elevation of liver $\mathrm{Cu}$ at slaughter 5 weeks later (Table 3). Dosing with CoSeCure elevated liver $\mathrm{Cu}$ to a smaller extent (Table 5). Se pellets seemed to have no effect on liver $\mathrm{Cu}$.

Liver Mo is shown in Tables 2-4. The $S$ lambs had the lowest means, and $\mathrm{Co} / \mathrm{B}_{12}$ supplementation most often elevated the values. The difference between all values of the unsupplemented $\mathrm{S}$ lambs and the values of the $\mathrm{SCo} / \mathrm{SB}_{12}$ lambs was significant $(\mathrm{p}<$ 
Table 3. Liver $\mathrm{Co}, \mathrm{Cu}, \mathrm{Mo}$, and $\mathrm{Mn}(\mathrm{mg} / \mathrm{kg}$ wet weight, mean $\pm \mathrm{sd})$ in lambs slaughtered on Oct. 11, 1982, and which had been grazing OWLD pastures $(\mathbf{S})$ or pastures where lambs grew well $(\mathrm{H})$. Three affected lambs were picked on Sept. 6 for treatment trials with copper and vitamin $B_{12}$.

\begin{tabular}{llllll}
\hline Group & $\mathrm{n}$ & $\mathrm{Co}$ & $\mathrm{Cu}$ & $\mathrm{Mo}$ & $\mathrm{Mn}$ \\
\hline $\mathrm{S}$ & 2 & $0.024 \pm 0.002$ & $2.9 \pm 0.1$ & $0.38 \pm 0.01$ & $4.3 \pm 1.0$ \\
$\mathrm{~S}-\mathrm{CuO}$ & 1 & 0.039 & 96 & 0.17 & 4.1 \\
$\mathrm{~S}-\mathrm{CuO} \& \mathrm{~B}_{12}$ & 1 & 0.022 & 74 & 1.14 & 2.7 \\
$\mathrm{~S}^{-B_{12}}$ & 1 & 0.030 & 1.6 & 0.71 & 3.5 \\
\hline $\mathrm{SCo}_{\mathrm{SB}}$ & 6 & $0.081 \pm 0.025$ & $3.5 \pm 1.2$ & $0.66 \pm 0.19$ & $4.0 \pm 0.5$ \\
$\mathrm{SB}$ & 7 & $0.070 \pm 0.025$ & $4.5 \pm 2.0$ & $0.89 \pm 0.13$ & $3.3 \pm 0.6$ \\
$\mathrm{H}$ & 4 & $0.021 \pm 0.012$ & $13 \pm 6.5$ & $0.96 \pm 0.13$ & 3.1 \\
\hline
\end{tabular}

$\mathrm{S} \quad:$ Lambs grazing OWLD pastures (OWLD lambs).

S-CuO : S lamb dosed (Sept. 6) with copper oxide needles $(2 \mathrm{~g})$.

$\mathrm{S}-\mathrm{CuO} \& \mathrm{~B}_{12}$ : S lamb dosed (Sept. 6) with $\mathrm{CuO}$ and vitamin $\mathrm{B}_{12}(2 \mathrm{mg})$.

$\mathrm{S}_{-\mathrm{SB}_{12}} \quad: \mathrm{S}$ lamb dosed (Sept. 6) with $\mathrm{B}_{12}$.

SCo : Lambs grazing OWLD pastures fertilized with Co.

$\mathrm{SB}_{12} \quad$ : Lambs on OWLD pastures injected fortnightly with $\mathrm{B}_{12}$.

$\mathrm{H} \quad$ : Lambs growing well on other pastures.

$\mathrm{n}=$ number of lambs examined.

0.001). CuO treatment significantly depressed liver Mo (Tables 3-4, p < 0.05). The highest liver Mo was found in the $\mathrm{H}$ lambs. The difference between the $\mathrm{H}$ and unsupplemented $\mathrm{S}$ lambs was significant $(\mathrm{p}<0.05)$ in 1982 and 1984.

Liver $\mathrm{Zn}$ is given in Tables 4-5. There was a tendency that $\mathrm{S}$ lambs had lower liver $\mathrm{Zn}$ than $\mathrm{H}$ lambs ( $\mathrm{p}<0.001$ in 1985), and that $B_{12}$ or Co treatment elevated values, while $\mathrm{CuO}$ treatment depressed them. The difference between the $\mathrm{S}$ and $\mathrm{SCuO}$ groups was significant $(\mathrm{p}<0.025)$.

Liver $\mathrm{Mn}$ is given in Tables 2, 3 and 5. In

Table 4. Liver $\mathrm{Co}, \mathrm{Cu}, \mathrm{Mo}$, and $\mathrm{Zn}(\mathrm{mg} / \mathrm{kg} \mathrm{ww})$ in lambs from various groups slaughtered on Sept. 26 1984. Four lambs were examined in each group $(n=4)$. Mean values \pm sd are given.

\begin{tabular}{llrll}
\hline Group & Co & \multicolumn{1}{l}{ Cu } & Mo & \multicolumn{1}{l}{$\mathrm{Zn}$} \\
\hline S & $0.021 \pm 0.010$ & $14 \pm 5.4$ & $0.87 \pm 0.42$ & $38 \pm 9$ \\
SCo & $0.026 \pm 0.007$ & $6.2 \pm 1.4$ & $1.25 \pm 0.20$ & $48 \pm 4$ \\
SB 12 & $0.066 \pm 0.010$ & $10 \pm 4.3$ & $0.96 \pm 0.23$ & $40 \pm 4$ \\
SCopell & $0.058 \pm 0.007$ & $6.1 \pm 2.3$ & $1.19 \pm 0.29$ & $43 \pm 4$ \\
SCuO & $0.006 \pm 0.002$ & $250 \pm 46$ & $0.40 \pm 0.07$ & $22 \pm 3$ \\
H & $0.024 \pm 0.009$ & $21 \pm 11$ & $1.42 \pm 0.12$ & $43 \pm 4$ \\
\hline
\end{tabular}

SCopell: Lambs dosed with cobalt pellets on June 25.

$\mathrm{SCuO}$ : Lambs dosed with copper oxide needles on May 15.

$\mathrm{SB}_{12}$ : Lambs injected every third week with $\mathrm{B}_{12}$.

For group symbols, see also Table 5. 
Table 5. Liver $\mathrm{Co}, \mathrm{Cu}, \mathrm{Fe}, \mathrm{Zn}$ and $\mathrm{Mn}(\mathrm{mg} / \mathrm{kg}$ ww, mean $\pm \mathrm{sd})$ in lambs from various groups, slaughtered Oct. 8 1985. Four lambs were examined in each group $(n=4)$, except in the SCo and $\mathrm{SCoSeCu}$ groups where $\mathrm{n}=3$.

\begin{tabular}{|c|c|c|c|c|c|}
\hline Group & Co & u & $\mathrm{Fe}$ & $\mathrm{Zn}$ & $\mathrm{Mn}$ \\
\hline $\mathbf{S}$ & $0.013 \pm 0.004$ & $4.2 \pm 0.6$ & $236 \pm 18$ & $36 \pm 5$ & $3.0 \pm 0.5$ \\
\hline SCo & $0.043 \pm 0.011$ & $7.3 \pm 3.2$ & $171 \pm 39$ & $40 \pm 4$ & 0.4 \\
\hline SCot & $0.048 \pm 0.006$ & $8.6 \pm 1.3$ & $128 \pm 23$ & $43 \pm 7$ & 0.6 \\
\hline $\mathrm{SCoSeCu}$ & $0.051 \pm 0.013$ & $17 \pm 9.8$ & $148 \pm 39$ & $42 \pm 11$ & $3.0 \pm 0.2$ \\
\hline SSe & $0.021 \pm 0.002$ & $7.7 \pm$ & $265=$ & $40 \pm 7$ & 2.9 \\
\hline $\mathrm{SB}_{12}$ & 0.077 & $6.7 \pm$ & 36 & $43 \pm 3$ & .3 \\
\hline $\mathrm{H}$ & $0.009 \pm 0.006$ & $18 \pm 11$ & $119 \pm 17$ & $47 \pm 3$ & 0.5 \\
\hline $\mathbf{S}$ & \multicolumn{5}{|c|}{ : Lambs grazing OWLD pastures. } \\
\hline SCo & \multicolumn{5}{|c|}{$\begin{array}{l}\text { Lambs grazing OWLD pastures fertilized with Co } \\
\left(\mathrm{CoSO}_{4}, 1 \mathrm{~kg} / \mathrm{ha}\right) \text { in } 1980,1981 \text { and } 1982 .\end{array}$} \\
\hline $\mathrm{SCo}+$ & \multicolumn{5}{|c|}{$\begin{array}{l}\text { Lambs grazing OWLD pastures fertilized with Co } \\
(1 \mathrm{~kg} / \mathrm{ha}) \text { in } 1980-1982,1984 \text { and } 1985 .\end{array}$} \\
\hline $\mathrm{SCoSeCu}$ & \multicolumn{5}{|c|}{$\begin{array}{l}\text { Lambs grazing OWLD pastures, dosed with cobalt-sele- } \\
\text { nium-copper glass boluses on July } 1 .\end{array}$} \\
\hline SSe & \multicolumn{5}{|c|}{$\begin{array}{l}\text { Lambs grazing OWLD pastures, dosed with selenium } \\
\text { pellets on July } 1 .\end{array}$} \\
\hline $\mathrm{SB}_{12}$ & \multicolumn{5}{|c|}{$\begin{array}{l}\text { Lambs grazing OWLD pastures, treated every third week } \\
\text { with } 2 \mathrm{mg} \text { hydroxocobalamin. }\end{array}$} \\
\hline H & \multicolumn{5}{|c|}{ : Lambs growing well on other pastures. } \\
\hline
\end{tabular}

1985 , liver Mn was significantly lower in the $\mathrm{S}$ lambs than in the $\mathrm{H}$ lambs $(\mathrm{p}<0.05$, Table 5), but this was not the case in 1982 . Liver Fe is shown in Table 5. The $\mathrm{S}$ lambs had higher levels at slaughter than the $\mathrm{H}$ lambs $(p<0.001)$. Co supplementation reduced liver $\mathrm{Fe}(\mathrm{p}<0.005)$, while Se and $\mathrm{B}_{12}$ dosing did not.

Mean liver Se was between 0.12 and 0.16 $\mathrm{mg} / \mathrm{kg} \mathrm{ww}$ in all groups, except in the Se treated groups (SSe, $\mathrm{SCoSeCu}$ ), where mean values were 0.46 and $0.25 \mathrm{mg} / \mathrm{kg}$ respectively. There were no significant differences between the $\mathrm{S}$ and $\mathrm{H}$ lambs, the overall mean value for the $\mathrm{H}$ lambs was $0.09 \mathrm{mg} / \mathrm{kg}$, while it was $0.10 \mathrm{mg} / \mathrm{kg}$ for the untreated $\mathrm{S}$ lambs. Mean values of total liver sulphur varied between $0.18 \mathrm{mg} / \mathrm{kg}$ ww and 0.25 , with no differences between the groups. At slaughter, mean values in all groups were between 0.21 and $0.25 \mathrm{mg} / \mathrm{kg}$ ww.

All pellets and boluses were recovered in the forestomacs at slaughter, with one exception, where no CoSeCure bolus could be found (Ulvund 1990c).

\section{Discussion}

Liver Co in healthy lambs is reported to be about $0.15 \mathrm{mg} / \mathrm{kg} \mathrm{dw}(0.05 \mathrm{mg} / \mathrm{kg} \mathrm{ww}$, Smith 1987), or between 0.1 and $0.3 \mathrm{mg} / \mathrm{kg}$ $\mathrm{dw}(0.03-0.9 \mathrm{mg} / \mathrm{kg}$ ww, Robertson 1971). In addition to amounts of $\mathrm{Co}$ in the liver, values of vitamin $B_{12}$ in liver and blood (Suttle 1986) and of methylmalonic acid (MMA) in blood (McMurray et al. 1985) are used to evaluate the Co status of sheep. In our case, the liver $\mathrm{Co}$ of all S, SSe and SCuO lambs were deficient, and correlated well 
with the low plasma $\mathrm{B}_{12}$ and elevated MMA seen in these lambs (Ulvund 1990b, c).

On average, the $\mathrm{H}$ grass had slightly higher Co content than the $\mathrm{S}$ grass (NS), but some years the Co content in $\mathrm{H}$ grass was lower (Ulvund \& Pestalozzi 1990b), and the $\mathrm{H}$ lambs were subclinically $B_{12}$ deficient (Ulvund 1990b). In spite of these conditions, the $\mathrm{H}$ lambs on average grew $17 \mathrm{~kg}$ more than the $\mathrm{S}$ lambs on pasture (Ulvund \& $\mathrm{Pe}$ stalozzi 1990a). It was surprising, therefore, that the livers from the $\mathrm{H}$ lambs contained just as little $\mathrm{Co}$ as the livers from the $\mathrm{S}$ lambs. The liver Co values of the $\mathrm{S}$ and $\mathrm{H}$ lambs are in accordance with the amounts found by others in both OWLD (Richards \& Harrison 1981, Mitchell et al. 1982) and Co deficiency (Robertson 1971, Schwan et al. 1987, Smith 1987). The supply of Co through pasture grass must have been too scarce to enable the fast growing $\mathrm{H}$ lambs to build up liver reserves. The better growth and lack of clinical symptoms in them as compared with the OWLD lambs, as well as the deficient liver $\mathrm{Co}$ in both, support the hypothesis that cofactors participate to promote fulminant OWLD.

The most effective way to enhance liver Co was regular $B_{12}$ injections, but treatment with Co pellets, $\mathrm{CoSeCu}$ boluses, or Co fertilization of pasture was almost equally effective. In the lambs grazing Co fertilized pastures, values were highest in 1982 and 1985, when Co fertilization was done the same year.

Liver $\mathrm{Cu}$ varies with breed, age, and composition of the diet, and individual variation may be considerable (Davis \& Mertz 1987). In Norway, optimal liver $\mathrm{Cu}$ is recognized to be about $50 \mathrm{mg} / \mathrm{kg} \mathrm{ww}$, values between 50 and $150 \mathrm{mg} / \mathrm{kg}$ reflect a moderate $\mathrm{Cu}$ overloading, values above $150 \mathrm{mg} / \mathrm{kg}$ may be sufficient to explain a $\mathrm{Cu}$ induced haemolytic crisis, and the lower marginal level for a $\mathrm{Cu}$ sufficiency is $10 \mathrm{mg} / \mathrm{kg}$ ww (Froslie 1977, Soli 1980). Caple \& McDonald (1983) report $\mathrm{Cu}$ deficiency at liver $\mathrm{Cu}$ below 10 $\mathrm{mg} / \mathrm{kg} \mathrm{dw}$ (3 mg/kg ww).

The low liver $\mathrm{Cu}$ content seen in both the $\mathrm{Co} / \mathrm{B}_{12}$ supplemented and the unsupplemented $\mathrm{S}$ groups probably reflects the lower amounts in the OWLD pasture grass (Ulvund \& Pestalozzi 1990b). According to Froslie (1977), adult healthy sheep from Rogaland, where the experiments were carried out, had lower mean liver $\mathrm{Cu}$ and larger range in individual values than sheep from other areas, and $15 \%$ of the liver samples at slaughter had below $10 \mathrm{mg} \mathrm{Cu} / \mathrm{kg}$ ww. The higher serum $\mathrm{Cu}$ seen in the earlier phase of OWLD, associated with liver damage, may also have caused depletion of liver stores (Ulvund 1990a).

In 3 lambs with severe OWLD in Tasmania, Mason \& McKay (1983) found low liver $\mathrm{Cu}$ $(0.6-8 \mathrm{mg} / \mathrm{kg} \mathrm{ww})$, and they claimed that the presence of normal serum $\mathrm{Cu}$ in spite of low liver contents was a feature of OWLD. Mitchell (1979) and Mitchell et al. (1982) found mean liver $\mathrm{Cu} 1.5 \mathrm{mmol} / \mathrm{kg}$ ww in OWLD lambs, as compared to values above 0.8 $\mathrm{mmol} / \mathrm{kg}$ for normal lambs in the area. The OWLD lambs, however, showed large individual variations $(0.12-5.7 \mathrm{mmol} / \mathrm{kg})$, which may reflect varying duration of disease. Lambs with OWLD may thus have normal liver $\mathrm{Cu}$ in the early phase of disease, but low amounts later.

A moderate hepatic damage as well as a moderate elevation of serum $\mathrm{Cu}$ was seen in $\mathrm{H}$ lambs with subclinical $\mathrm{B}_{12}$ deficiency (Ulvund 1990a, b). H grass contained significantly more $\mathrm{Cu}$ than $\mathrm{S}$ grass (Ulvund \& Pestalozzi 1990b). Although mean liver $\mathrm{Cu}$ was higher in the $\mathrm{H}$ lambs, possibly reflecting the higher $\mathrm{Cu}$ intake, these lambs showed great individual variation, and several had values below $10 \mathrm{mg} / \mathrm{kg}$ ww. The low 
values may represent some degree of hepatic loss.

In Swedish unthrifty lambs with reported Co and $\mathrm{Cu}$ deficiency, liver $\mathrm{Cu}$ was on average $13 \mathrm{mg} / \mathrm{kg}$ ww (Schwan et al. 1987). In weaners affected with coast disease, a concurrent deficiency of $\mathrm{Co}$ and $\mathrm{Cu}$ in Australia, Marston et al. (1938) found very low liver $\mathrm{Cu}(2-3 \mathrm{mg} / \mathrm{kg} \mathrm{ww})$, but no significant alteration in serum $\mathrm{Cu}$. Treatment with $\mathrm{Cu}$ alone had no effect on the progress of the disease, whereas treatment with Co permitted growth in some, but a combination of $\mathrm{Co}$ and $\mathrm{Cu}$ was necessary for complete recovery. Dosing with $\mathrm{CuO}$ needles resulted in toxic amounts of liver $\mathrm{Cu}$ in all $\mathrm{S}$ lambs of both the Rygja and the Dala breeds. Whitelaw et al. (1983), who also dosed $\mathrm{CuO}$ needles $(2 \mathrm{~g})$ to lambs at 3-5 weeks of age, found that these lambs grew well and had adequate liver $\mathrm{Cu}$ at weaning $(463 \mathrm{mg} / \mathrm{kg} \mathrm{dw}$, i.e. 139 $\mathrm{mg} / \mathrm{kg} \mathrm{ww}$ ). In another examination, Whitelaw et al. (1982) dosed $\mathrm{CuO}$ needles $(1 \mathrm{~g})$ at 5 weeks of age, and these lambs had mean liver $\mathrm{Cu} 255 \mathrm{mg} / \mathrm{kg} \mathrm{dw}(77 \mathrm{mg} / \mathrm{kg} \mathrm{ww})$ at weaning. No signs of toxicity were detected. Suttle (1987) reported $\mathrm{Cu}$ toxicity in 1 out of 4 ewes, which had received $20 \mathrm{~g} \mathrm{CuO}$ particles, but none of those receiving smaller doses showed any signs of toxicity. The livers of our lambs dosed with $\mathrm{Cu}$ on OWLD pastures seemingly had increased affinity for $\mathrm{Cu}$. In lupinosis of sheep, which occurs on $\mathrm{Cu}$ deficient pastures, Gardiner (1966b) found elevated serum $\mathrm{Cu}$, and liver $\mathrm{Cu}$ was increased when the sheep were $\mathrm{Cu}$ supplemented. Alkaloids in Heliotropium europaeum may also damage the liver in such a way that it retains Cu (Seaman 1987). The high liver $\mathrm{Cu}$ obtained after $\mathrm{CuO}$ dosing in our lambs indicated that they had a similar hepatic damage (Ulvund 1990e).

When $\mathrm{Co}$ and Se were dosed together with the $\mathrm{Cu}(\mathrm{SCoSeCu})$, liver $\mathrm{Cu}$ was lower.
Values were also lower than those reported by others in dosing experiments. Driver et al. (1986) dosed $\mathrm{CoSeCu}$ glass boluses to 7 months old $\mathrm{Cu}$ deficient lambs, and found mean liver $\mathrm{Cu}$ between 211 and $136 \mathrm{mg} / \mathrm{kg}$ $\mathrm{dw}(63-41 \mathrm{mg} / \mathrm{kg} \mathrm{ww})$ in the dosed, as compared to $32 \mathrm{mg} / \mathrm{kg} \mathrm{dw}(9.6 \mathrm{mg} / \mathrm{kg}$ ww) in the undosed, 5 months after dosing. Allen et al. (1984) also found higher liver $\mathrm{Cu}$ in lambs 3-7 months after dosing with $\mathrm{Cu}$ glass boluses, mean values in the treated and control groups were 108 and $56 \mathrm{mg} / \mathrm{kg}$ ww respectively.

Dissolution rate of the glass bullets vary (Trengrove \& Hudson 1985), but complete dissolvement has not been described. The liver of the lamb which had no CoSeCure bullet at slaughter contained $307 \mathrm{mg} \mathrm{Cu} / \mathrm{kg}$ ww, $0.05 \mathrm{mg} \mathrm{Co} / \mathrm{kg}$ and $0.69 \mathrm{mg} \mathrm{Se} / \mathrm{kg}$. The values indicate dissolvement and absorbtion of the bullet, and increased affinity for $\mathrm{Cu}$ in the liver.

$\mathrm{Cu}$ retention in the liver is influenced by dietary $\mathrm{Mo}, \mathrm{Zn}, \mathrm{Cd}, \mathrm{Fe}$ and $\mathrm{Ca}$ (Davis \& Mertz 1987). OWLD grass had significantly lower Mo content than $\mathrm{H}$ grass (Ulvund \& Pestalozzi 1990b). Normal liver Mo in sheep is often $2-4 \mathrm{mg} / \mathrm{kg} \mathrm{dw}(0.6-1.2 \mathrm{mg} / \mathrm{kg}$ $w w)$, and the content is not only influenced by the amount in the diet, but also by dietary sulphate (Mills \& Davis 1987). As the sulphur content in the OWLD grass did not differ from the $\mathrm{H}$ grass (Ulvund \& Pestalozzi 1990b), the low liver Mo found in the $S$ lambs may reflect lower Mo intakes, and/or liver damage and leakage. $\mathrm{Co} / \mathrm{B}_{12}$ supplementation of $\mathrm{S}$ lambs increased liver Mo to values which were similar to those found in the $\mathrm{H}$ lambs, and to values found in healthy lambs from eastern Norway (Froslie \& Norheim 1976), results indicating that prevention of liver damage enabled the liver to store more Mo. 
Froslie \& Norheim (1976) found no difference in liver Mo between healthy lambs with low and high liver $\mathrm{Cu}$ respectively, but sheep dead of chronic $\mathrm{Cu}$ poisoning had lower liver Mo than sheep surviving the $\mathrm{Cu}$ accumulation, a pattern indicating that a decrease in liver Mo may occur in the terminal state of $\mathrm{Cu}$ poisoning. The results may indicate leakage from a damaged liver, and may thus be in accordance with the condition of our OWLD lambs.

Low intake of Mo favours the accumulation of $\mathrm{Cu}$ in the liver, and can lead to chronic $\mathrm{Cu}$ poisoning (Søli 1980, Davis \& Mertz 1987, Mills \& Davis 1987). The low Mo intake may therefore also be an important factor explaining the increased affinity for $\mathrm{Cu}$ in the liver of our lambs. Spais et al. 1966) found that Mo favoured the liver storage of $\mathrm{Co}$, but that sulphate inhibited it. Low dietary Mo may therefore have favoured $\mathrm{Co}$ depletion as well as $\mathrm{Cu}$ accumulation.

The fact that increased $\mathrm{Cu}$ intake depresses liver Mo was clearly demonstrated in our $\mathrm{SCuO}$ lambs, as also reported by (Spais et al. 1966).

$\mathrm{S}$ grass had significantly lower $\mathrm{Zn}$ content than H grass (Ulvund \& Pestalozzi 1990b), which probably explains the lower liver $\mathrm{Zn}$ values seen in the unsupplemented $S$ lambs. All values were, however, within the range reported for normal lambs from eastern Norway (Frøslie \& Norheim 1976). In Sweden, values about $30 \mathrm{mg} / \mathrm{kg}$ ww are normally found (Schwan 1987). Normal values of liver $\mathrm{Zn}$ in lambs in Western Australia were above $100 \mathrm{mg} / \mathrm{kg} \mathrm{ww}$, and 28 OWLD lambs had $133 \mathrm{mg} / \mathrm{kg}$ ww (Richards \& Harrison 1981). A fall in serum $\mathrm{Zn}$ is indicative of $\mathrm{Zn}$ deficiency in lambs (Suliman et al. 1988). As serum $\mathrm{Zn}$ was normal in all our lambs (Ulvund 1990a), a $\mathrm{Zn}$ deficiency can pro- bably be ruled out in the OWLD pathogenesis.

$\mathrm{CuO}$ treatment lowered liver $\mathrm{Zn}$, which is in accordance with the $\mathrm{Cu} / \mathrm{Zn}$ competitive mechanism (Bremner et al. 1976, Soli 1980). The interaction seen between $\mathrm{Co}$ and $\mathrm{Zn}$, resulting in elevation of liver $\mathrm{Zn}$ after $\mathrm{Co} / \mathrm{B}_{12}$ dosing, may indicate a certain degree of leakage of $\mathrm{Zn}$ from a damaged liver, and that prevention of this damage by $\mathrm{Co} / \mathrm{B}_{12}$ increases liver retention of $\mathrm{Zn}$ as well.

$\mathrm{S}$ grass had significantly lower $\mathrm{Mn}$ contents than $\mathrm{H}$ grass (Ulvund \& Pestalozzi 1990b), but this was not reflected in liver $\mathrm{Mn}$ contents. There is therefore reason to believe that the Mn was more easily absorbed or stored in the OWLD lambs. The lack of constant differences between $\mathrm{S}$ and $\mathrm{H}$ lambs regarding liver $\mathrm{Mn}$, however, probably indicates that $\mathrm{Mn}$ plays no role in the etiology of OWLD. The values within all groups were regarded as normal, as liver $\mathrm{Mn}$ of healthy sheep is given to be $8-10 \mathrm{mg} / \mathrm{kg} \mathrm{dw}(2.4-3$ $\mathrm{mg} / \mathrm{kg}$ ww, Hurley \& Keen 1987).

$\mathrm{S}$ grass had significantly higher Fe contents than $\mathrm{H}$ grass (Ulvund \& Pestalozzi 1990b), and the higher liver $\mathrm{Fe}$ found in the $\mathrm{S}$ lambs, may be due to higher intakes. The values may, however, also indicate a further similarity between OWLD and coast disease. In 12 weaners with coast disease, the liver on average contained about twice as much $\mathrm{Fe}$ $(740 \mathrm{mg} / \mathrm{kg} \mathrm{ww})$ as normal sheep of the area (300 mg/kg ww, Marston et al. 1938). High liver $\mathrm{Fe}$ has also been found in pure Co deficiency (Robertson 1971). The lowered liver $\mathrm{Fe}$ seen in the $\mathrm{SCo}, \mathrm{SCo}+$ and $\mathrm{SCoSeCu}$ lambs, but not in the $\mathrm{SB}_{12}$ lambs, is probably due to the fact that high dietary intakes of Co may interfere with intestinal Fe absorption (Morris 1987).

Liver Se was judged to be adequate to marginal in our lambs (Caple \& McDonald 1983, Frøslie et al. 1980). Results indicate that 
OWLD had no effect on liver Se, which is in accordance with findings by Richards \& Harrison (1981) and Andrews et al. (1964). Increased liver Se was found after dosing with Se pellets (Andrews et al. 1974). In our case, dosing with Se pellets was more effective in raising liver Se than dosing with $\mathrm{CoSeCu}$ glass boluses. Lack of effect of $\mathrm{Se}$ on liver $\mathrm{Cu}$, as observed in the present study, was also reported by Gardiner (1966a). The slight increase of liver Co seen after $\mathrm{Se}$ dosing has not been reported by others, is difficult to explain, and is dealt with elsewhere (Ulvund 1990e).

Generally the OWLD livers contained increased lipid (Ulvund 1990e), and this may have affected the comparisons to some extent.

The lack of difference in liver Co between OWLD lambs and normally growing lambs on other pastures ( $\mathrm{H}$ lambs) is intriguing, but correlates to some extent with earlier findings regarding plasma $B_{12}$, and further supports the hypothesis that cofactors are necessary for the fulminant development of OWLD. Based on liver $\mathrm{Cu}$ and $\mathrm{Mo}$, a role of the $\mathrm{Cu}$ /Mo relationship in the OWLD pathogenesis can so far not be excluded.

\section{References}

Allen WM, Sansom BF, Gleed PT, Mallinson $C B$, Drake $C F$ : Boluses of controlled release glass for supplementing ruminants with copper. Vet. Rec. 1984, 115, 55-57.

Andrews ED, Grant AB, Brunswick LFC: An assessment of the effects of ruminal selenium pellets given to young sheep grazing seleniumdeficient pastures. N. Z. vet. J. 1974, 22, 4650.

Andrews ED, Grant AB, Stephenson BJ: Weight responses of sheep to cobalt and selenium in relation to vitamin $B_{12}$ and selenium concentrations in liver and kidney. N. Z. J.-agric. Res. 1964, 7, 17-27.
Bremner I, Young BW. Mills CF: Protective effect of zinc supplementation against copper toxicosis in sheep. Brit. J. Nutr. 1976, 36, 551561.

Caple IW, McDonald JW: Trace mineral nutrition. Refresher Course, University of Sidney, 1983, 67, 235-265.

Davis GK, Mertz W: Copper. In Mertz W. (ed.): Trace elements in human and animal nutrition, 5th ed., vol. 1, Academic Press, London 1987, 301-364.

Driver PM, Eames C, Telfer SB: Efficasy of soluble glass boluses containing copper, cobalt and selenium in store lambs. In Proc. 6th Int. Conf. on production disease in farm animals, Belfast 1986, 108-111.

Frank A: Automated wet ashing and multi-metal determination in biological material by atomic-absorption spectrometry. Z. anal. Chem. 1976, 279, 101-102.

Frank A, Petersson LR: Selection of operating conditions and analytical procedure in multimetal analysis of animal tissues by d.c. plasmaatomic emission spectroscopy. Spectrochim. Acta 1983, 38, B, 207-220.

Froslie A, Kobberstatus hos sau i Norge. (Copper state of sheep in Norway). Norsk Vet.-T. 1977, 89, 71-79.

Froslie A, Karlsen JT, Rygge J: Selenium in animal nutrition in Norway. Acta agric. scand. 1980, 30, 17-25.

Froslie A, Norheim G: The concentrations of molybdenum and zinc in liver in relation to copper accumulation in normal and copper poisoned sheep. Acta vet. scand. 1976, 17, 307315.

Gardiner MR: Chronic selenium toxicity studies in sheep. Aust. vet. J. 1966a, 42, 442-448.

Gardiner MR: Mineral metabolism in sheep lupinosis. II. Copper. J. comp. Path. 1966b, 76, 107-120.

Halvorsen HM, Personal communication, 1989.

Hurley LS, Keen CL: Manganese. In: Mertz W.: (ed.): Trace elements in human and animal nutrition, 5th ed., vol. 1, Academic Press, London 1987, 185-223.

Marston HR. Thomas RG, Murnane D, Lines EWL, McDonald IW, Moore HO, Bull LB: 
Studies on coast disease of sheep in South Australia. Council for Scientic and Industrial Research, Bull. no. 113, Melbourne 1938, 91 pp.

Mason $R W$, McKay $R$ : Ovine white liver disease. Aust. vet. J. 1983, 60, 219-220.

McMurray CH, Rice DA, McLoughlin $M$, Blanchflower WJ: Cobalt deficiency and the potential of using methylmalonic acid as a diagnostic and prognostic indicator. In: Mills CF, Bremner I, Chesters JK (eds.): Trace elements in man and animals. TEMA-5. Proc. 5th Int. Symp. on trace elements in man and animals, Aberdeen 1984. CAB, London 1985, p. 603-608.

Mills $C F$, Davis GK: Molybdenum. In: Mertz W. (ed.): Trace elements in human and animal nutrition, 5th ed., vol. 1, Academic Press, London 1987, 429-463.

Mitchell PJ: Studies on ovine white liver disease in East Gippsland. Vict. vet. Proc. 1979, 37, 30.

Mitchell PJ, McOrist S, Thomas KW, McCausland $P$ : White liver disease of sheep. Aust. vet. J. 1982, 58, 181-184.

Morris ER: Iron. In: Mertz W. (ed.): Trace elements in human and animal nutrition, 5th. ed., vol. 1, Academic Press, London 1987, 97 -98 .

Norheim G: Personal communication, 1989.

Richards RB, Harrison MR: White liver disease in lambs. Aust. vet. J. 1981, 57, 565-568.

Robertson $W W$ : Cobalt deficiency in ruminants. Vet. Rec. 1971, 89, 5-12.

Schwan O, Jacobsson SO, Frank A, Rudby-Martin $L$, Petersson $R$ : Cobalt and copper deficiency in Swedish landrace pelt sheep. J. vet. Med. A, 1987, 34, 709-718.

Seaman JT: Pyrrolizidine alkaloid poisoning of sheep in New South Wales. Aust. vet. J. 1987, 64, 164-167.

Smith RM: Cobalt. In Mertz W. (ed.): Trace elements in human and animal nutrition, vol. 1, Academic Press, London 1987, 143-183.

Spais A, Papasteriadis A, Agiannidis A, Lazaridis $T$ : Action of inorganic sulphate, sulphide, cyanide and molybdenum on liver cobalt in lambs. Rep. vet. Fac. Univ. Thessaloniki, 1966, 7, 167-174.

Suliman HB, Abdelrahim AI. Zakia AM, Shommein $A M$ : Zinc deficiency in sheep: Field cases. Trop. Anim. Health Prod. 1988, 20. 47-51.

Suttle NF: Problems in the diagnosis and anticipation of trace element deficiencies in grazing livestock. Vet. Rec. 1986, 119, 148-152.

Suttle NF: Safety and effectiveness of cupric oxide particles for increasing liver copper stores in sheep. Res. Vet. Sci. 1987, 42, 219-223.

Soli NE: Chronic copper poisoning in sheep. A review of the literature. Nord. Vet.-Med. 1980, $32,75-89$.

Trengove $C L$, Judson GJ: Trace element supplementation of sheep: evaluation of various copper supplements and a soluble glass bullet containing copper, cobalt and selenium. Aust. vet. J. 1985, 62, 321-324.

Ulvund MJ: Ovine white-liver disease (OWLD). Changes in blood chemistry. Acta vet. scand. 1990a, 31, 277-286.

Ulvund MJ: Ovine white-liver disease (OWLD). Vitamin $\quad \mathbf{B}_{12}$ and methylmalonic acid (MMA) estimations in blood. Acta vet. scand. 1990b, 31, 267-275.

Ulvund MJ: Ovine white-liver disease (OWLD). Serum Copper and effects of copper and selenium supplementation. Acta vet. scand. 1990c, 31, 287-295.

Ulvund MJ: Ovine white-liver disease (OWLD). Treatment trials. Acta vet. scand. 1990d, 31.

Ulvund MJ: Ovine white-liver disease (OWLD). Pathology. Acta vet. scand. 1990e,31, 309-324.

Ulvund MJ, Pestalozzi M: Ovine white-liver disease (OWLD) in Norway. Clinical symptoms and preventive measures. Acta vet. scand. 1990a, 31, 53-62.

Ulvund MJ, Pestalozzi M: Ovine white-liver disease (OWLD). Botanical and chemical composition of pasture grass. Acta vet. scand. 1990b, 31, 257-265.

Whitelaw A, Fawcett AR, MacDonald AJ: Cupric oxide needles in the prevention of swayback. Vet. Rec. 1982, 110, 522. 
Whitelaw A, Russel AJF, Armstrong RH, Evans $C C$, Fawcett AR, MacDonald AJ: Use of cupric oxide needles in the prophylaxis of induced copper deficiency in lambs grazing improved hill pastures. Vet. Rec. 1983, 112, 382384.

\section{Sammendrag}

Kvitleversjuke (kobolt/vitamin $B_{12}$ mangel) hos lam. Sporstoffinnhold i leveren.

Sporstoffinnholdet i leveren ble undersøkt hos vitamin $B_{12}$-deficitte lam som utviklet kvitleversjuke (OWLD, S-lam), hos lam som gikk på de samme beitene men ble dosert med kobolt/-vitamin $B_{12}, o g$ hos klinisk friske som gikk på andre beiter, men som enkelte år var subklinisk $\mathrm{B}_{12}$ deficitte (H-lam). Koboltinnholdet i leveren var mar- ginalt til deficitt både hos lam med kvitleversjuke (S) og H-lam. Behandling med vitamin $\mathrm{B}_{12}$ eller ekstra tilskud av kobolt økte innholdet av Co i leveren. Innholdet av kopper var signifikant lavere hos OWLD affiserte lam, og $\mathrm{Co} / \mathrm{B}_{12}$ behandling av lam på disse beitene så ikke ut til å øke innholdet. Dosering med kopperoksydnåler resulterte i svært høye/toksiske nivå av $\mathrm{Cu}$ i leveren. Dosering med kobolt/selen/kopper glassboli resulterte i adekvat kopperinnhold, bortsett fra ett lam som hadde toksiske mengder, noe som tydet på oppløsning og absorbsjon av bolus. Lam med kvitleversjuke hadde signifikant lavere innhold av molybden $\mathrm{i}$ leveren enn $\mathrm{H}$-lamma, og $\mathrm{Co} / \mathrm{B}_{12}$ behandling resulterte i økning av innholdet, mens kopperbehandling førte til en senkning. Innholdet av sink, mangan og selen er også oppgitt.

(Received February 7, 1989; accepted October 9, 1989).

Reprints may be requested from: Martha J. Ulvund, State Veterinary Research Station for Small Ruminants, Høyland, P. O. Box 264, N-4301 Sandnes, Norway. 